\title{
The Assessment of the Serum C-Peptide and Plasma Glucose Levels by Orally Administered Whey Proteins in Type 2 Diabetes Mellitus
}

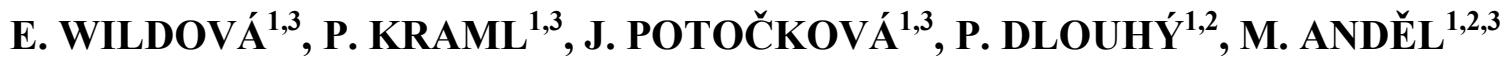 \\ ${ }^{1}$ Center for Research on Diabetes, Metabolism and Nutrition, Third Faculty of Medicine, Charles \\ University, Prague, Czech Republic, ${ }^{2}$ Department of Hygiene, Third Faculty of Medicine, Charles \\ University, Prague, Czech Republic, ${ }^{3}$ Second Department of Internal Medicine University Hospital \\ Královské Vinohrady and Third Faculty of Medicine, Charles University, Prague, Czech Republic
}

Received September 1, 2016

Accepted June 2, 2017

On-line September 22, 2017

\section{Summary}

A personalized antidiabetic therapy is not yet part of the official guidelines of professional societies for clinical practice. The aim of this study was to evaluate the serum C-peptide and plasma glucose levels in patients with type 2 diabetes mellitus (T2DM) after oral administration of whey proteins. Sixteen overweight T2DM Caucasians with good glycemic control and with preserved fasting serum C-peptide levels (>200 nmol/l) were enrolled in this study. Two oral stimulation tests - one with $75 \mathrm{~g}$ of glucose (OGTT) and the other with $75 \mathrm{~g}$ of whey proteins (OWIST) were administered for assessing serum C-peptide and plasma glucose levels in each participant. Both oral tests induced similar pattern of C-peptide secretion, with a peak at $90 \mathrm{~min}$. The serum C-peptide peak concentration was $2.91 \pm 0.27 \mathrm{nmol} / \mathrm{l}$ in OWIST, which was $22 \%$ lower than in OGTT. Similarly, the C-peptide iAUC $_{0-180}$ were $32 \%$ lower in the OWIST than in the OGTT $(p<0.01)$. Contrary to OGTT the OWIST did not cause a significant increase of glycemia $(p<0.01)$. Our study showed that the OWIST represents a useful tool in estimation of stimulated serum C-peptide levels in patients with T2DM.

\section{Key words}

Stimulated C-peptide secretion - Whey proteins • Oral glucose tolerance test $\bullet$ T2DM

\section{Corresponding author}

E. Wildová, Center for Research on Diabetes, Metabolism and Nutrition, Third Faculty of Medicine of the Charles University in Prague, Ruská 2411/87, 10000 Prague, Czech Republic. E-mail: elena.wildova@lf3.cuni.cz

\section{Introduction}

Type 2 diabetes mellitus (T2DM) is a chronic heterogeneous disease characterized by progressive loss of insulin secretion ( $\beta$-cell dysfunction) in parallel with impaired whole-body insulin sensitivity (American Diabetes Association 2016). It is well established (DeFronzo 1988) that a chronic hyperglycemia is primarily caused by various degrees of impaired insulin sensitivity (insulin resistance) and secondarily by $\beta$-cell dysfunction as a manifestation of the progressive loss of the pancreatic islet $\beta$-cell followed by a decreasing maximal capacity of insulin secretion. Importantly, progressive decline in insulin secretion is affecting different patients to a different degree (U.K. Prospective Diabetes Study 16 1995, Saisho 2015). Progressive loss of $\beta$-cell function is often associated with deterioration of T2DM control, i.e. a higher level of glycated hemoglobin $(\mathrm{HbA} 1 \mathrm{c})$, and therefore with higher risk of long-term complications (DeFronzo 2009). Better understanding of mechanisms driving $\beta$-cell dysfunction as well as development of specific test evaluating actual insulin secretion in large number of patients in a routine clinical setting is highly needed. Insulin secretion is often evaluated indirectly in clinical practice and research by studying C-peptide secretion, because its levels are more stable in blood circulation and C-peptide is released from $\beta$-cell in pancreas in equimolar amount to insulin.

Several clinical studies showed that knowledge of stimulated serum C-peptide secretion (Meier et al. 
2009) should be an accurate marker for the treatment decision for each patient at the beginning and during the course of the disease (U.K. Prospective Diabetes Study 16 1995, Wajchenberg 2007). Majority of T2DM patients have: 1) preserved fasting C-peptide levels and at least twice as high postprandial serum C-peptide levels, 2) a preponderance of insulin deficiency and have preserved fasting but reduced postprandial serum C-peptide levels (i.e. C-peptide levels not rising above twice the value of fasting C-peptide; Ratheiser et al. 1990), and 3) reduced fasting and postprandial C-peptide levels. It seems that the patients in the two last groups would benefit from early initiation of exogenous therapy with insulin (Harrison et al. 2012).

This approach of setting personalized antidiabetic therapy is not yet part of the official guidelines of professional societies for clinical practice (Monnier et al. 2006, Robertson 2007, Roy et al. 2007, American Diabetes Association 2016). The main reason seems to be the lack of a standardized insulin secretion stimulation test. Insulin secretion stimulation tests frequently used in clinical trials - mixed meal tolerance test (MMTT), oral glucose tolerance test (OGTT) or glucagon stimulation test (GST) - mostly cause hyperglycemia and are time-consuming. In our previous paper, we showed that standard OGTT and orally whey administration had a comparable effect on C-peptide secretion in healthy participants (Wildova et al. 2013).

Therefore, the aim of this study was to compare the serum C-peptide and plasma glucose levels after administration of whey protein concentrate (OWIST) and standard OGTT in T2DM patients achieving a good glycemic control. The overarching goal was to define, whether OWIST might represent a tool investigating insulin secretion in a clinical setting.

\section{Methods}

\section{Patients}

Sixteen overweight Caucasians (6 men and 10 women; aged 56-80 years, BMI (body mass index): $26.4-29.8 \mathrm{~kg} / \mathrm{m}^{2}$ ), with T2DM (Genuth et al. 2003), with a glycated hemoglobin (HbAlc) level less than $58 \mathrm{mmol} / \mathrm{mol}(7.5 \%)$ at the time of recruitment, normal or higher fasting C-peptide secretion $(0.39-1.33 \mathrm{nmol} / \mathrm{l})$ and 5 years or longer after diagnosis of T2DM were enrolled in this study. All participants were treated with metformin $(500 \mathrm{mg}$ dose per day), had a prescribed diabetic diet and were engaged in regular physical activity. Additionally, all participants were generally in good health, with no signs or symptoms of any acute diseases, renal insufficiency or lactose intolerance. Insulin resistance by Homa2 IR was $2.42 \pm 0.23$; mean \pm SEM (Levy et al. 1998).

\section{Study protocol}

We used a controlled cross-over study design to evaluate fasting and stimulated C-peptide secretion after the administration of the whey proteins (OWIST) and glucose alone (OGTT) in patients with T2DM.

OGTT drink contained $75 \mathrm{~g}$ oral glucose load (Glukopur; Natura, Hamry u Havlíčkova Brodu, Czech Republic) in $300 \mathrm{ml}$ of water (Small et al. 1985).

OWIST drink consisted of $75 \mathrm{~g}$ of flavored whey proteins (whey protein concentrate 80, WPC 80) in $300 \mathrm{ml}$ of water so that it had the same dose as OGTT. The WPC 80 was manufactured by Volactive UltraWhey80; DVN, Hoogeveen, the Netherlands and it contained $81 \%$ high-quality nutritional whey proteins, $6 \%$ lactose, $6 \%$ fat, $4 \%$ moisture and $3 \%$ minerals, flavoured with $0.4 \mathrm{~g}$ of strawberry aroma AFFRAI 0005 (RJP International, Prague, Czech Republic) and $0.4 \mathrm{~g}$ of vanilla extract (RAPS-CZ, Prague, Czech Republic).

The study protocol was designed in accordance to the principles of the Helsinki Declaration and received prior approval by the Ethics Committee of the Third Faculty of Medicine, Charles University, Prague, Czech Republic. All participants were fully informed and gave their written consent.

All patients with T2DM underwent both tests after overnight fasting for at least $12 \mathrm{~h}$. They were tested on two different occasions in a random order within a one month period. The tests were carried out in the research unit of the 2nd Department of Internal Medicine at the University Hospital Královské Vinohrady, Prague, Czech Republic. Both of tests were performed at 8 a.m., when a peripheral venous catheter was inserted for obtaining samples of venous blood into the antecubital vein using the aseptic technique. The participants rested quietly on bed during the test. Samples for fasting values of the plasma glucose levels and serum C-peptide measurement were collected at time 0 (just before administration of the OGTT or OWIST). Within $3 \mathrm{~min}$ the drink was administered. Other blood samples were collected at 30 , 60, 90, 120 and $180 \mathrm{~min}$ in a closed blood collection system (S-Monovette; Sarstedt, Nümbrecht, Germany) after the drink administration. The catheter was flushed with $0.9 \%$ saline after each blood sample draw. 
The samples for the serum C-peptide concentration determination were centrifuged for $15 \mathrm{~min}$ at $3,000 \mathrm{~g}$ Jouan BR4i (DJB Labcare, Buckinghamshire, England) and analyzed using a 2-site immunochemiluminometric assay by the Immunolite 2000 immunoassay system (Diagnostic Products Corporation, Los Angeles, California, USA). The analytical range of the assay was $0.17-2.32 \mathrm{nmol} / 1$ and the lower limit of sensitivity was $0.017 \mathrm{nmol} / 1$. The inter- and intra-assay coefficients of variation $(\mathrm{CVs})$ were less than $6 \%$. The plasma glucose levels were determined using the hexokinase method by a Konelab Glucose analyzer (Thermo Fisher Scientific Oy, Vantaa, Finland). The detection limit was $0.1 \mathrm{mmol} / \mathrm{l}$. Side effects of both OGTT and OWIST were evaluated in regards to hyperglycemia and general tolerance (nausea, vomiting).

\section{Statistics}

The incremental area under the curve (iAUC) of glucose and C-peptide in OWIST and OGTT were calculated using the trapezoid rule for both the plasma glucose levels and the serum C-peptide levels. For the serum C-peptide concentration, several iAUCs were calculated: $\mathrm{iAUC}_{0-30}$ (the early phase of insulin secretion), $\mathrm{iAUC}_{0-90}$ (insulin secretion during a proposed shorter measurement period), $\mathrm{iAUC}_{0-180}$ (the whole measured insulin secretion), $\mathrm{iAUC}_{30-180}$ (the late phase of insulin secretion). For the plasma glucose level only iAUC $_{0-180}$ was calculated.

Statistical comparison between the total C-peptide response and plasma glucose level, relative to the reference was carried out using the two-sided paired Student's t-test (assumptions were tested using Fisher's test of equality of variances and the KolmogorovSmirnov normality test). Pearson's product moment correlation was used for testing the association between the paired samples of data values.

All the data in the text are presented as mean \pm SEM. All statistical hypotheses were tested at a significance level of 0.01 using $\mathrm{R}$ software (2.14.1, R Foundation for Statistical Computing, Vienna, Austria) with Bonferroni corrections for multiple comparisons.

Modified version of the insulinogenic index (Wareham et al. 1995, Tura et al. 2006) was calculated as:

$$
\mathrm{IGI}=\mathrm{C}_{30}-\mathrm{C}_{0} / \mathrm{G}_{30}
$$

where $\mathrm{C}_{30}$ is the serum C-peptide concentration at $30 \mathrm{~min}, \mathrm{C}_{0}$ is the fasting serum C-peptide concentration and $\mathrm{G}_{30}$ is the plasma glucose level at $30 \mathrm{~min}$.

\section{Results}

\section{C-peptide response}

The average fasting level of the serum C-peptide was $0.94 \pm 0.07 \mathrm{nmol} / 1$. Both oral tests resulted in a similar shape of the C-peptide response curve, with a peak at $90 \mathrm{~min}$. In the case of OGTT (reference), the serum C-peptide concentration peaked at $3.72 \pm 0.30 \mathrm{nmol} / \mathrm{l}$. The serum C-peptide peak concentration was $2.91 \pm 0.27 \mathrm{nmol} / 1$ in OWIST, which was $22 \%$ lower than in OGTT. Subsequent serum C-peptide concentrations steadily decreased after $90 \mathrm{~min}$ (OWIST) and $120 \mathrm{~min}$ (OGTT) while not reaching the baseline within the test duration of $180 \mathrm{~min}$. Individual serum C-peptide concentrations after the OWIST were significantly lower $(\mathrm{p}<0.01)$ at 90, 120, $180 \mathrm{~min}$ than after the OGTT. Both tests induced the same slope of C-peptide curve in the first $30 \mathrm{~min}$ (the early phase of insulin secretion). Data are summarized in Figure 1.

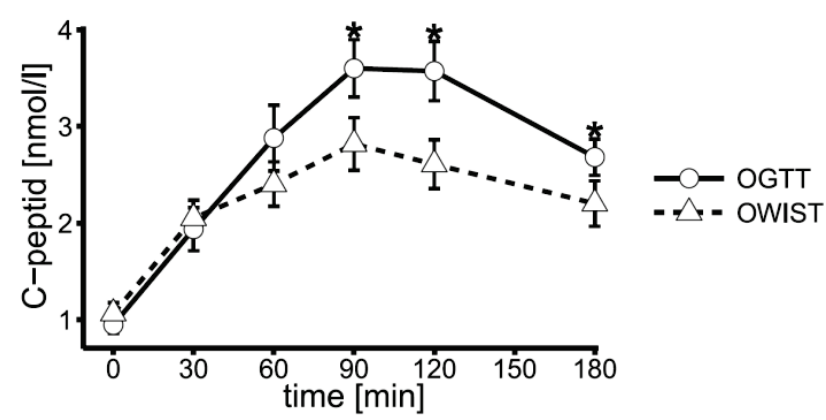

Fig. 1. The absolute values (mean \pm SEM) of the serum C-peptide levels in response to oral tests - OGTT (reference) and OWIST in patients with T2DM $(n=16) . *$ indicates values significantly different from the reference $(p<0.01)$.

\section{Glucose response}

The average fasting plasma glucose level (baseline) was $8.11 \pm 0.57 \mathrm{mmol} / \mathrm{l}$. The OGTT showed a plasma glucose level peak at $19.1 \pm 1.33 \mathrm{mmol} / 1$. After $90 \mathrm{~min}$, the curve was steadily decreasing towards the baseline, but not reaching it within the test duration. Contrary to OGTT the OWIST did not cause a significant increase of glycemia $(p<0.01)$. Data are summarized in Figure 2.

The assessment of the C-peptide secretion and glycemic response in patients with T2DM

The average fasting plasma glucose level (baseline) was $8.11 \pm 0.57 \mathrm{mmol} / \mathrm{l}$. The administration of the OGTT increased glycemia, on average 2.1 times, on the other hand, the administration of the OWIST did not 
induce a glycemia increase (plasma glucose level $8.89 \pm 1.15 \mathrm{mmol} / 1$ at $120 \mathrm{~min}$ ). The incremental area under the curve of the whole measured C-peptide response (iAUC $\mathrm{i}_{0-180}$ ) was $32 \%$ lower after the OWIST, in comparison to the OGTT. Data are summarized in Table 1.

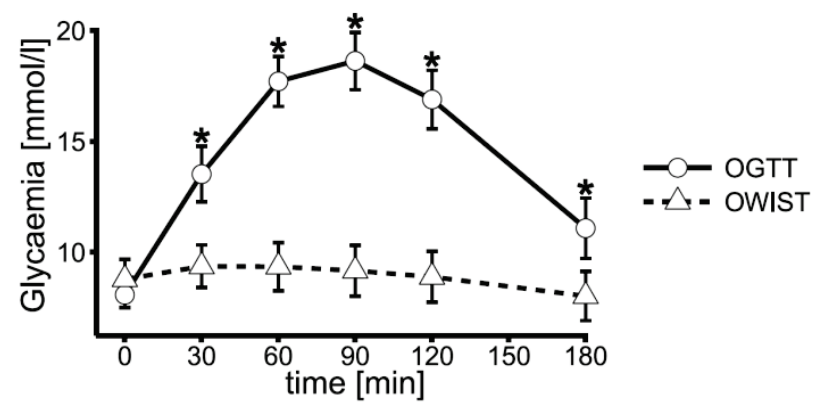

Fig. 2. The absolute values (mean \pm SEM) of the plasma glucose levels in response to oral tests - OGTT (reference) and OWIST in patients with T2DM $(n=16)$. * indicates values significantly different from the reference $(p<0.01)$.
The early phase of insulin secretion (iAUC $\mathrm{in}_{0-30}$ ) was similar for both the OGTT and the OWIST. The IGI, calculated from the OWIST and OGTT, correlates with each other $(p<0.01)$, while being $47 \%$ higher after the administration of OWIST. No correlation was found between the stimulated late phase insulin secretion (iAUC ${ }_{30-180}$ ) using the OGTT and OWIST, however the OGTT stimulation achieved a $34 \%$ higher iAUC $_{30-180}$ than the OWIST. Furthermore, a very strong correlation $(\mathrm{r}=0.94 ; \mathrm{p}=0.0002)$ was found between the $\mathrm{iAUC}_{0-90}$ and iAUC $_{0-180}$ for both OGTT and OWIST.

\section{Side effects}

The OWIST was well-tolerated by all participants. The administration of the OGTT induced nausea in three participants and eight participants complained about the unusual sweet taste of the drink. In two participants, the OGTT induced hyperglycemia had to be managed with insulin administration. No other side effects were observed.

Table 1. Measurements of the fasting and stimulated C-peptide and plasma glucose levels during the OGTT and OWIST.

\begin{tabular}{|c|c|c|c|}
\hline & OGTT & OWIST & $\Delta \%$ \\
\hline Plasma glucose - fasting [mmol/l] & $8.11 \pm 0.57$ & $8.13 \pm 0.54$ & $0 \%$ \\
\hline Plasma glucose - $120 \mathrm{~min}$ value [mmol/l] & $16.89 \pm 1.32$ & $8.89 \pm 1.15$ & $-47 \%{ }^{*}$ \\
\hline C-peptide - fasting [nmol/l] & $0.94 \pm 0.07$ & $0.92 \pm 0.11$ & $2 \%$ \\
\hline C-peptide - peak [nmol/l] & $3.72 \pm 0.30$ & $2.91 \pm 0.27$ & $-22 \%{ }^{*}$ \\
\hline C-peptide - iAUC $C_{0-30}[\mathrm{nmol.min} / \mathrm{l}]$ & $15.00 \pm 2.70$ & $15.20 \pm 2.10$ & $1 \%$ \\
\hline C-peptide - iAUC $C_{0-90}[\mathrm{nmol} . \mathrm{min} / \mathrm{l}]$ & $128.40 \pm 18.30$ & $97.90 \pm 10.40$ & $-24 \%$ \\
\hline C-peptide - iAUC $30-180[$ nmol.min/l] & $324.50 \pm 37.00$ & $214.80 \pm 21.10$ & $-34 \%{ }^{*}$ \\
\hline C-peptide - iAUC $C_{0-180}[$ nmol.min/l] & $339.50 \pm 38.90$ & $230.00 \pm 21.90$ & $-32 \%{ }^{*}$ \\
\hline Plasma glucose $-i A U C_{0-180}[\mathrm{mmol} . \mathrm{min} / \mathrm{ll}]$ & $1251.00 \pm 109.40$ & $89.30 \pm 29.70$ & $-92 \%{ }^{*}$ \\
\hline $\operatorname{IGI}\left[10^{-3}\right]$ & $0.56 \pm 0.12$ & $0.82 \pm 0.13$ & $47 \%{ }^{*}$ \\
\hline
\end{tabular}

The values show mean \pm SEM. The $\Delta \%$ column indicated the mean percentage change between the OGTT (reference) and OWIST. $*$ t-test $(p<0.01)$ OGTT vs. OWIST.

\section{Discussion}

International Diabetes Association annually updates its recommendations for clinical practice based on the state-of-the-art findings from clinical trials. Assessment of the $\beta$-cell function, i.e. stimulated insulin (C-peptide) secretory response, has not yet been implemented in the official recommendations even though several clinical trials demonstrate its impact on therapy of T2DM (Kramer et al. 2013) and sometimes even in type 1 diabetes mellitus (Greenbaum et al. 2008).

Our results demonstrated that the OWIST correctly assessed the stimulated C-peptide secretion (both the early and late phase of insulin secretion) in patients with T2DM. The results indicate that the oral stimulus (both glycemic and non-glycemic) administered to the patients with well-controlled T2DM leads to a characteristic shape of stimulated C-peptide secretion with a peak at $90 \mathrm{~min}$. The administration of OWIST induced C-peptide $\mathrm{iAUC}_{0-30}$ that was similar to the 
$\mathrm{iAUC}_{0-30}$ induced by administration of OGTT. This corresponds with the fact that both whey proteins and glucose activate a cephalic and entero-insular axis in a similar way (Salehi et al. 2012). A linear trade-off was found between the OGTT and OWIST values of the IGI that corresponds with the early phase of insulin secretion (Wareham et al. 1995). The IGI is commonly used because it highly correlates with the acute insulin response (AIR) during the intravenous glucose tolerance test (Kosaka et al. 1996) and is considered a sensitive marker of insulin secretion after glucose stimulus (Tura et al. 2006, Kahn et al. 2001). It was suggested that the progressive loss of the total $\beta$-cell number in the islets of Langerhans first becomes apparent as a disorder of the early phase of the stimulated insulin or C-peptide secretion, followed by a disorder of the late phase (Calles-Escandon and Robbins 1987) with a more pronounced concomitant postprandial hyperglycemia (Del Prato 2003) and unsatisfactory diabetes control. As iAUC $0-180$ was highly correlated with iAUC i-90 $_{0}$ after the administration of both the OGTT and OWIST, it seems that in order to assess the late phase of insulin secretion, a 90-minute-long test is sufficient. However, confirmation on a larger number of patients is needed.

Our study showed that the patients with well-controlled T2DM had their insulin secretion preserved or, more precisely, their stimulated maximum serum C-peptide concentration was at least twice their fasting level (Kahn et al. 2001).

The late phase of insulin secretion ( iAUC $_{30-180}$ ) is primarily regulated by the substrate phase of the insulin secretion. C-peptide secretion after administration of whey proteins is induced mainly by high level of plasma branched-chain amino acids and to a lesser degree by incretin hormones (Frid et al. 2005). A lower C-peptide secretion after OWIST (by $34 \%$ ) than after OGTT suggests that in patients with T2DM, the glucose stimulus was a stronger secretagogue than the BCAA in this phase.

In conclusion, we demonstrated that the OWIST is able to sufficiently evaluate the stimulated C-peptide secretion without a concomitant increase of plasma glucose level or hypoglycemia. We assume that the OWIST might prove useful for the evaluation of both the early and late phase of insulin secretion. It seems that the administration of whey proteins as a non-glucose stimulus is suitable for the stimulated insulin secretion testing for other groups of patients with diabetes (diabetes mellitus type 1 , gestational diabetes etc.), where increase of plasma glucose after the OGTT is often unacceptable.

\section{Conflict of Interest}

There is no conflict of interest.

\section{Acknowledgements}

The study was supported by the National Agency for Agricultural Research (grant NAZV 101B090) and was conducted in cooperation with the company MILCOM. The authors are grateful for essential help with paper: Jan Polák, M.D. for kind remarks, Ing. Jiří Wild, Ph.D. for the statistical analysis and advice on the statistical presentation and Mr. Harvey Cook for English proofreading.

\section{References}

AMERICAN DIABETES ASSOCIATION: Standards of medical care in diabetes - 2016 abridged for primary care providers. Clin Diabetes 34: 3-21, 2016.

CALLES-ESCANDON J, ROBBINS DC: Loss of early phase of insulin release in humans impairs glucose tolerance and blunts thermic effect of glucose. Diabetes 36: 1167-1172, 1987.

CREUTZFELDT W: The entero-insular axis in type 2 diabetes - incretins as therapeutic agents. Exp Clin Endocrinol Diabetes 109: 288-303, 2001.

DEFRONZO RA: Lilly lecture 1987. The triumvirate: beta-cell, muscle, liver. A collusion responsible for NIDDM. Diabetes 37: 667-687, 1988.

DEFRONZO RA: Banting Lecture. From the triumvirate to the ominous octet: a new paradigm for the treatment of type 2 diabetes mellitus. Diabetes 58: 773-795, 2009.

DEL PRATO S: Loss of early insulin secretion leads to postprandial hyperglycaemia. Diabetologia 46: M2-M8, 2003.

FRID AH, NILSSON M, HOLST JJ, BJÖRCK IM: Effect of whey on blood glucose and insulin responses to composite breakfast and lunch meals in type 2 diabetic subjects. Am J Clin Nutr 82: 69-75, 2005. 
GENUTH S, ALBERTI KG, BENNETT P, BUSE J, DEFRONZO R, KAHN R, KITZMILLER J, KNOWLER WC, LEBOVITZ H, LERNMARK A, NATHAN D, PALMER J, RIZZA R, SAUDEK C, SHAW J, STEFFES M, STERN M, TUOMILEHTO J, ZIMMET P; EXPERT COMMITTEE ON THE DIAGNOSIS AND CLASSIFICATION OF DIABETES MELLITUS: Follow-up report on the diagnosis of diabetes mellitus. Diabetes Care 26: 3160-3167, 2003.

GREENBAUM CJ, MANDRUP-POULSEN T, MCGEE PF, BATTELINO T, HAASTERT B, LUDVIGSSON J, POZZILLI P, LACHIN JM, KOLB H; TYPE 1 DIABETES TRIAL NET RESEARCH GROUP; EUROPEAN C-PEPTIDE TRIAL STUDY GROUP: Mixed-meal tolerance test versus glucagon stimulation test for the assessment of beta-cell function in therapeutic trials in type 1 diabetes. Diabetes Care 31: 1966-1971, 2008.

GUNNERUD UJ, ÖSTMAN EM, BJÖRK IM: Effects of whey proteins on glycaemia and insulinaemia to an oral glucose load in healthy adults: a dose-response study. Eur J Clin Nutr 67: 749-753, 2013.

HARRISON LB, ADAMS-HUET B, RASKIN P, LINGVAY I: $\beta$-cell function preservation after 3.5 years of intensive diabetes therapy. Diabetes Care 35: 1406-1412, 2012.

KAHN SE, MONTGOMERY B, HOWELL W, LIGUEROS-SAYLAN M, HSU CH, DEVINENI D, MCLEOD JF, HOROWITZ A, FOLEY JE: Importance of early phase insulin secretion to intravenous glucose tolerance in subjects with type 2 diabetes mellitus. J Clin Endocrinol Metab 86: 5824-5829, 2001.

KOSAKA K, KUZUYA T, HAGURA R, YOSHINAGA H: Insulin response to oral glucose load is consistently decreased in established non-insulin-dependent diabetes mellitus: the usefulness of decreased early insulin response as a predictor of non-insulin-dependent diabetes mellitus. Diabet Med 13: 109-119, 1996.

KRAMER CK, CHOI H, ZINMAN B, RETNAKARAN R: Determinants of reversibility of $\beta$-cell dysfunction in response to short-term intensive insulin therapy in patients with early type 2 diabetes. Am J Physiol Endocrinol Metab 305: E1398-E1407, 2013.

LEVY J, ATKINSON AB, BELL PM, MCCANCE DR, HADDEN DR: Beta-cell deterioration determines the onset and rate of progression of secondary dietary failure in type 2 diabetes mellitus: the 10-year follow-up of the Belfast Diet Study. Diabet Med 15: 290-296, 1998.

MARI A, PACINI G, MURPHY E, LUDVIK B, NOLAN JJ: A model-based method for assessing insulin sensitivity from the oral glucose tolerance test. Diabetes Care 24: 539-548, 2001.

MEIER JJ, MENGE BA, BREUER TG, MÜLLER CA, TANNAPFEL A, UHL W, SCHMIDT WE, SCHRADER H: Functional assessment of pancreatic beta-cell area in humans. Diabetes 58: 1595-1603, 2009.

MONNIER L, COLETTE C, THUAN JF, LAPINSKI H: Insulin secretion and sensitivity as determinants of HbA1c in type 2 diabetes. Eur J Clin Invest 36: 231-235, 2006.

POLIDORI D, MARI A, FERRANNINI E: Canagliflozin, a sodium glucose co-transporter 2 inhibitor, improves modelbased indices of beta cell function in patients with type 2 diabetes. Diabetologia 57: 891-901, 2014.

RATHEISER K, REITGRUBER W, KOMJATI M, BRATUSCH-MARRAIN P, VIERHAPPER H, WALDHAUSL WK: Quantitative and qualitative differences in basal and glucose- and arginine-stimulated insulin secretion in healthy subjects and different stages of NIDDM. Acta Diabetol Lat 27: 197-213, 1990.

ROBERTSON RP: Estimation of beta-cell mass by metabolic tests: necessary, but how sufficient? Diabetes 56: 2420-2424, 2007.

ROY MN, BISWAS KB, SIDDIQUA N, ARSLAN MI, ALI L: Determinants of insulin secretion and sensitivity in bangladeshi type 2 diabetic subjects. Metab Syndr Relat Disord 5: 275-281, 2007.

SAISHO Y: $\beta$-cell dysfunction: its critical role in prevention and management of type 2 diabetes. World J Diabetes 6 : 109-124, 2015.

SALEHI A, GUNNERUD U, MUHAMMED SJ, OSTMAN E, HOLST JJ, BJÖRCK I, RORSMAN P: The insulinogenic effect of whey protein is partially mediated by a direct effect of amino acids and GIP on $\beta$-cells. Nutr Metab 9: 48, 2012.

SMALL M, COHEN HN, BEASTALL GH, MACCUISH AC: Comparison of oral glucose loading and intravenous glucagon injection as stimuli to C-peptide secretion in normal men. Diabet Med 2: 181-183, 1985.

TURA A, KAUTZKY-WILLER A, PACINI G: Insulinogenic indices from insulin and C-peptide: comparison of beta-cell function from OGTT and IVGTT. Diabetes Res Clin Pract 72: 298-301, 2006. 
U.K. PROSPECTIVE DIABETES STUDY 16: Overview of 6 years' therapy of type II diabetes: a progressive disease U.K. Prospective Diabetes Study Group. Diabetes 44: 1249-1258, 1995.

WAJCHENBERG BL: Beta-cell failure in diabetes and preservation by clinical treatment. Endocr Rev 28: 187-218, 2007.

WAREHAM NJ, PHILLIPS DI, BYRNE CD, HALES CN: The 30 minute insulin incremental response in an oral glucose tolerance test as a measure of insulin secretion. Diabet Med 12: 931, 1995.

WILDOVA E, DLOUHY P, KRAML P, RAMBOUSKOVA J, SMEJKALOVA V, POTOCKOVA J, ANDEL M: Orally administered whey proteins have comparable effect on C-peptide secretion in healthy subjects as standard C-peptide stimulation tests. Physiol Res 62: 179-186, 2013. 